\title{
General notice
}

Since its promulgation in 1962, Korean corporate law, which is a chapter of the Korean Commercial Code (KCC) has been developed under the influence of Continental European corporate law statutes, cases, and scholarly works. Until 1962, Korea used Japanese corporate law, which was a chapter of the Japanese Commercial Code (JCC). (Japanese corporate law was promulgated in 1899 adapting to the German corporate law and was completely revised after the Second World War in 1950 modeled after the U.S. Illinois Business Corporation Act of 1933.) However, Korean corporate law is undergoing significant changes, strongly influenced by that of the United States since 1997. The KCC (which is within the domain of the Korean Ministry of Justice) has been generally revised in 1984, 1995, 1998, 1999, 2001, 2009 and 2011. The recent general revision in 2011 will greatly modify Korean corporate law, and it is scheduled to be enforced on April 15, 2012.

Practically, the more important source of Korean corporate law used to be the Korean Securities and Exchange Act (KSEA), which was within the domain of the Korean Ministry of Finance and Economy. The KSEA was promulgated in 1962 and has been revised numerous times especially after 1997. However, the KSEA was repealed and partially replaced by the KCC and the Korean Financial Investment Services and Capital Markets Act (KCMA) on February 4, 2009. The stock company in Korea can exist as a private or as a public company such as a "Korea Exchange-listed company" or "KOSDAQ-listed company." In addition to the requirements of the KCC related to the corporate governance of private companies, public companies are also partially subject to provisions of the $\mathrm{KCC}$ and the KCMA which are generally not applicable to private companies.

In Korea, certain companies engaged in a specialized business (such as banking, securities, or insurance) will be subject to additional regulations and requirements in terms of corporate governance under the relevant laws, i.e., the Korean Banking Act, etc. Directors of financial institutions may be subject to a stricter liability regime.

Disclaimer: No part of this book should be construed as legal advice or opinion of the professional organizations with which some contributors to this book work. The contributors, editor and publisher are not responsible for any action taken by the reader on the basis of this book. 